\title{
ANTI FUNGAL ACTIVITY OF WOOD EXTRACT \\ OF Aquilaria crassna Pierre ex Lecomte AGAINST AGARWOOD-INDUCING FUNGI, Fusarium solani
}

\author{
Eka Novriyanti ${ }^{1,2}$, Erdy Santosa ${ }^{3}$, Wasrin Syafii ${ }^{4}$, Maman Turjaman $^{3}$, \\ and Irnayuli R. Sitepu ${ }^{3}$
}

\begin{abstract}
This paper provided information regarding artificial agarwood production. Fungi are considered as biological agent for agarwood formation and agarwood is assumed as tree defense mechanism product. This research was aimed at investigating the anti fungal activity (AFA) of Aquilaria crassna, one of the agarwood-producing trees, against Fusarium solani in vitro. Aquilaria crassna wood mill was extracted by $70 \%$ ethanol to investigate the anti fungal activity. The result are Aquilaria crassna exhibited low extractives content, which was only $2.0 \%$ (w/w) and a low anti fungal activity in vitro, especially for ethanol extract. However, further fractionation and bioassay showed that the most active component was likely in the ethyl-acetate soluble fraction that exhibited strong anti fungal activity $(52.5 \%)$ at $4.0 \%$ of concentration.
\end{abstract}

Keywords: Artificial agarwood production, agarwood-producing tree, extractives, in vitro anti fungal activity-assay

\section{INTRODUCTION}

Agarwood is considered as the most exalted perfumery material because it imparts a unique lasting odor to the perfumery products. This commodity in fact is yielded from rich resinous heartwood of agar tree as a wounding or a pathogenesis embarked on tree stem. Its use as a perfume has been recorded in the Old Testament, also, agarwood has been used in traditional alleviation (Barden et al. 2000). These and other uses continue today.

Since agarwood occurrence is believed as plant responses to pathogen infection or wounding, thus, not every tree of these plants contains agarwood. Agarwood quality is formed along the process of its forming development, while the highest quality is achieved at the end of the process that usually takes time (Sumadiwangsa and Harbagung, 2000). The agarwood is produced by some tropical trees of Thymeleaceae family, whereas two genera of its most sought sources, i.e. Aquilaria and Gyrinops, have been listed in

\footnotetext{
${ }^{1}$ Research Institute of Fiber Producing Forest, FORDA, Jl. Raya Bangkinang-Kuok km 9 Kampar Riau.

${ }^{2}$ Corresponding Author. Email: kee_november09@yahoo.com

${ }^{3}$ Laboratory of Microbiology of Forest and Nature Conservation Research and Development Center, Bogor

${ }^{4}$ Department of Forest Products, Faculty of Forestry, Bogor Agricultural University, Darmaga Campus of

Bogor Agricultural University, Bogor.
} 
Appendix II CITES (CITES, 2004; Blanchette, 2006) because the declination of their natural resources. The declination is due to the intensive indiscriminate felling in their natural habitat that is stimulated by high price and market demand of the product.

Artificial agarwood production to offset demand for the lack of wild stock, has been developed but it seems likely such efforts have not appeared satisfactorily, in terms of both commercial quality and quantity. Researches in aiming the better production of artificial agarwood have increased and developed for the last decades (e.g. Barden et al., 2000; Persoon and Van Beek, 2008). However, it is important to ensure the guarantee of the continuity of the agarwood formation by artificial induction (Blanchette, 2006). Once the induction takes place, many factors affect the continuity of the agarwood formation, such as environment, the inducing agent, the genetic or condition of the tree, and human interference (Agrios, 1997).

Agarwood is a plant phytoalexin that is formed after plant suffer an attack, thus it is an induced defense of agarwood-producing trees (Isnaini, 2004; Novriyanti, 2008). However, large variation in agarwood forming should consider variation in phytoanticipin (i.e. constitutive defense) of the plants that usually consist of phenolic compound in its mechanism. This plant phytoanticipin would determine the tree susceptibility to agarwood formation.

Defense mechanism of certain plants is due to its genetic. Tree builds defense against stress or disease through certain ways, physically or chemically. The chemical composition of the tree is considered as one of its defense system. As for agarwood, its forming is poorly understood, but it is assumed as part of tree defense mechanism against the causal agents, either environmental stress or disease (Barden et al., 2000). Therefore, observation on agarwood tree chemicals, especially secondary metabolites, is essential to select the potential susceptible tree for the agarwood formation. The assumption is that the more susceptible tree would respond well to the induction of agarwood forming agents, and then tree with the less defense compounds would be more preferred in artificial agarwood production.

The agarwood causal agent could be divided into chemical, physical, and biological agents (Prema and Bhattacharyya, 1962; Sumarna, 2005; Pojanagaroon and Kaewrak, 2006). Mechanical injury could be considered as physical inducer of agarwood formation, as the induction of some chemicals, such as oil, sugar, or methyl jasmonate is considered as chemical inducer. Fungi are considered as one of the biological agents that induce agarwood formation. This biological agent is more preferred since its formation development is considered progressive (Erdy Santoso, personal communication).

The research was aimed at investigating the anti fungal activity that possibly exists in Aquilaria crassna wood extract and its corresponding fractions against Fusarium solani fungi (biological agent of agarwood inducer), in vitro. The susceptible tree to the agarwood formation is considered as one that has the less anti fungal compounds. 


\section{MATERIALS AND METHODS}

\section{A. Materials}

Wood of $A$. crassna was collected from agarwood stands at Dramaga Research Forest, Bogor. The source tree was about 10 years old (it was planted in 1998). Ethanol, n-hexane, ethyl acetate, and buthanol were used as solvent for extraction. F. solani (Gorontalo, Indonesia origin, isolate number: FORDA-CC 00509) and assay media were obtained from Laboratory of Microbiology of Forest and Nature Conservation Research and Development Center, Bogor. The assay media were potato dextrose agar (PDA). The PDA media was prepared by boiling $100 \mathrm{~g}$ of potato to get the extract out. Then the acquired extract was added with $20 \mathrm{~g}$ of dextrose and $10 \mathrm{~g}$ of agar before passing into $1000 \mathrm{ml}$ of solution.

\section{B. Extraction and Fractionation}

Wood mill of $A$. crassna that passed through 40-mesh screen but retained on 60mesh was extracted following modified-method by Wu et al. (2005). We used wood mill instead of small wood-pieces as mentioned in Wu et al. (2005) and we used buthanol instead of water in this research. Afterwards, $2 \mathrm{~kg}$ of the wood mill was extracted in $70 \%$ ethanol until the extract solution obtained was clear. This ethanol extract was then successively fractionated by using n-hexane $\left(\mathrm{n}-\mathrm{C}_{6} \mathrm{H}_{14}\right)$, ethyl acetate (EtOAc), and buthanol $(\mathrm{BuOH})$ in order to acquire dissolved fractions of $\mathrm{n}$-hexane, EtOAc, $\mathrm{BuOH}$, and residue (Figure 1).

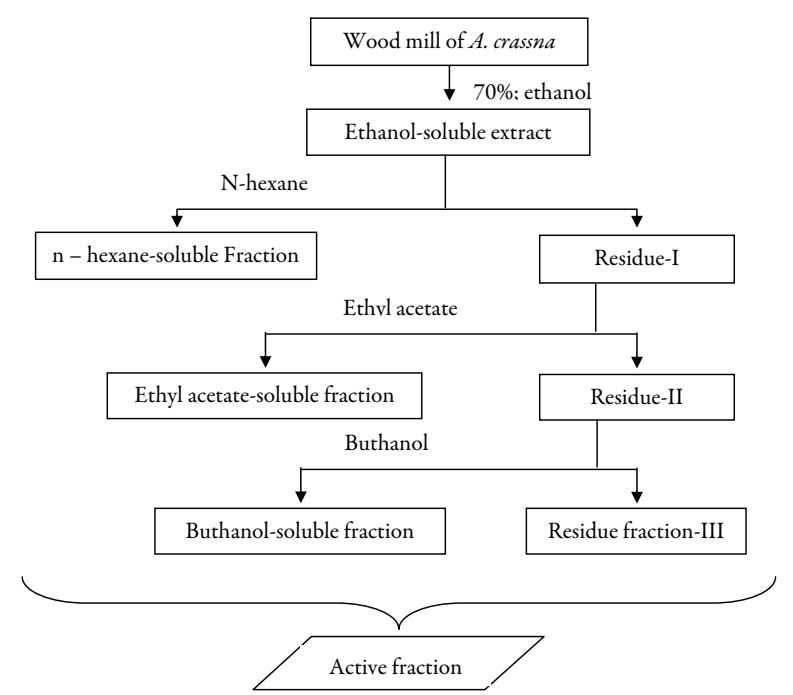

Figure 1. Fractionation scheme of $A$. crassna wood mill 
We use the scheme in Figure 1 to group the extracted-compounds based on their polarity. We expect $n$-hexane would retain oils and waxs from the crude ethanol extract, and then we targeted phenolic acids and flavonols from the ethyl acetate fractionation, and phenol resins from buthanol fraction.

The content of ethanol-soluble extract, its corresponding fractions (n-hexanesoluble, ethyl acetate-soluble, and buthanol-soluble), and the residue in the wood mill were determined based on extract in oven dry weight per wood mill in oven dry weight $(\%, w / w)$.

\section{Antifungal Bioassay Against $F$. solani fungi}

Ethanol-soluble extract; n-hexane-soluble, ethyl acetate-soluble, and buthanolsoluble fractions; as well as residue fraction were assayed against $F$. solan $i$ in plate. Each of the fractions was made in concentrations of $0 \%$ (control), $1 \%, 2 \%, 3 \%, 4 \%$, and $5 \%$ (w/w, extract weight/agar media weight). The research was arranged in a completely randomized design with those concentration levels as the factor, in three replications. The PDA media were prepared in sterile condition. Prior to addition of the extract, the assay media were sterilized by autoclaving for 15 minutes at $121^{\circ} \mathrm{C}$ and $1.05 \mathrm{~kg} / \mathrm{cm}^{2}$ pressure. Afterwards, each extract was added to the media. Once the media solidified, the mycelial plug of $F$. solani ( $5 \mathrm{~mm}$ in diameter) was inoculated to the media. Control media were added with $2 \mathrm{ml}$ ethanol, since the dilutive agent for the extracts was ethanol. After 10 days of incubation, the mycelium growth was measured $(\mathrm{mm})$. The anti fungal activity (AFA) was measured following Mori et al. (1997).

$$
\mathrm{AFA}(\%)=\frac{\text { GC-GT }}{\mathrm{GC}-\mathrm{A}} \times 100 \%
$$

Where: AFA: anti fungal activity (\%); GC: mycelia growth of control or $0 \%$ concentration $(\mathrm{mm})$; GT: mycelia growth of treatment $(\mathrm{mm}) ; \mathrm{A}$ : mycelia diameter at the initiation of the assay $(\mathrm{mm})$

Based on AFA value, activity of each fraction was then classified into activity category level (Table 1). The classification of AFA referred to classification by Mori et al. (1997) that was familiar in bioassay against fungi. The most active fraction against F. solani is resulted from bioassay. This active fraction is assumed to contain the most active compound to inhibit $F$. solani growth. The tree with higher concentration of the most active anti fungal compound should be avoided in artificial agarwood production. 
Table 1. Classification of anti fungal activity level

\begin{tabular}{cc}
\hline Antifungal activity (AFA) & Activity level \\
\hline AFA $\geq 75 \%$ & Very strong $(++++)$ \\
$75 \% \leq \mathrm{AFA}<50 \%$ & strong $(+++)$ \\
$50 \% \leq \mathrm{AFA}<25 \%$ & moderate $(++)$ \\
$25 \% \leq \mathrm{AFA}<0$ & weak $(+)$ \\
0 & not active $(-)$ \\
\hline
\end{tabular}

Source: Mori et al. (1997)

\section{RESULTS AND DISCUSSION}

Result of extraction and fractionation revealed that only $2.0 \%$ of extractives content and most of them were semi polar compounds (Table 2). It was quite low extractives content in a tree, whereas other tropical tree could contain extractives more than 10\% of its dry weight, as the case for extractive content of wood bark of Acacia auriculiformis A. Cunn. ex Benth. that can reach up to 19.7\% (Yanti, 2008). Lestari and Pari (1990) mentioned that extractives content is classified as high if wood contains it more than 4\%. Low extractives content resulted in this study was probably due to the nature of the healthy wood of $A$. crassna. The healthy wood of aquilaria usually white-yellowish in color, soft in texture, and light in weight (Adelina, 2004), those characteristic are common at wood with low content of extractives. Low extractives content is common character of fast growing species such as aquilaria.

Table 2. Extractives content of $A$. crassna

\begin{tabular}{lclc}
\hline & Concentration $\left.(\%, \mathrm{w} / \mathrm{w})^{*}\right)$ & Fractions $\left.{ }^{* *}\right)$ & $\begin{array}{c}\text { concentration } \\
\left.(\%, \mathrm{w} / \mathrm{w})^{*}\right)\end{array}$ \\
\hline Ethanol extract & 2.0 & n-hexane & 0.2 \\
& Ethyl acetate & 0.6 \\
& Buthanol & 0.3 \\
& Residue & 0.9 \\
\hline Total & Total & 2.0 \\
\hline Remarks: ${ }^{*}$ Calculated based on oven dry weight; $\left.{ }^{* *}\right)$ for the fractionation scheme please refer to \\
$\quad$ Figure 1
\end{tabular}


Classification by Mori et al. (1997) showed that ethanol extract of $A$. crassna in average had low anti fungal activity (AFA), which is $15.2 \%$ (Figure 2 and 3 ). However, successive fractionation of ethanol extract into n-hexane, ethyl acetate, and buthanol showed increasing of AFA against $F$. solani.

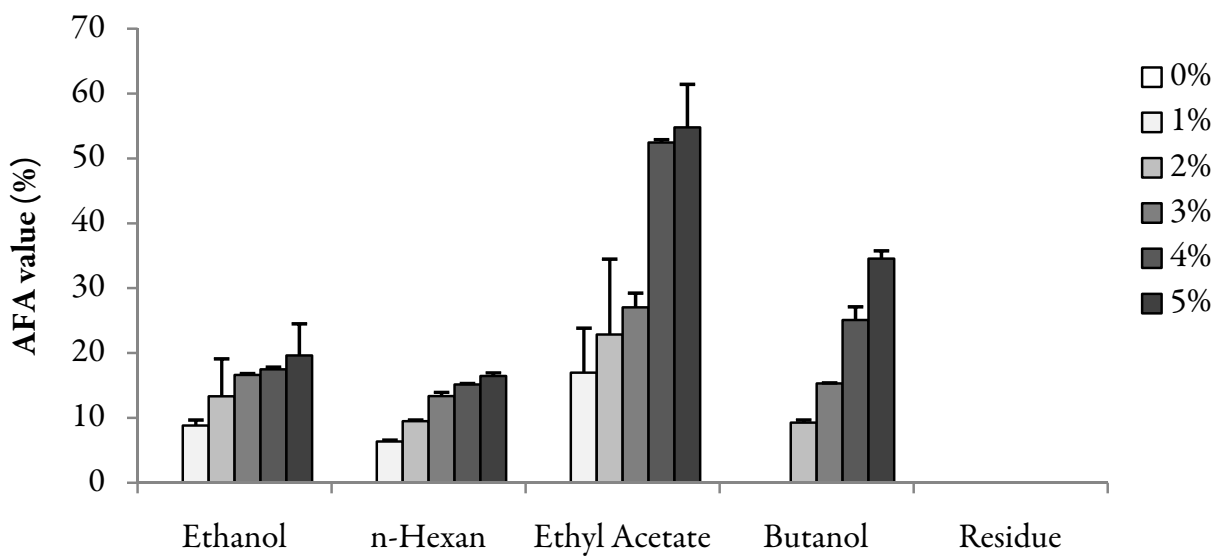

Figure 2. AFA value of ethanol-soluble extract and its corresponding fractions, specified by the extract/fraction concentrations $(1 \%, 2 \%, 3 \%, 4 \%$, and $5 \%)$

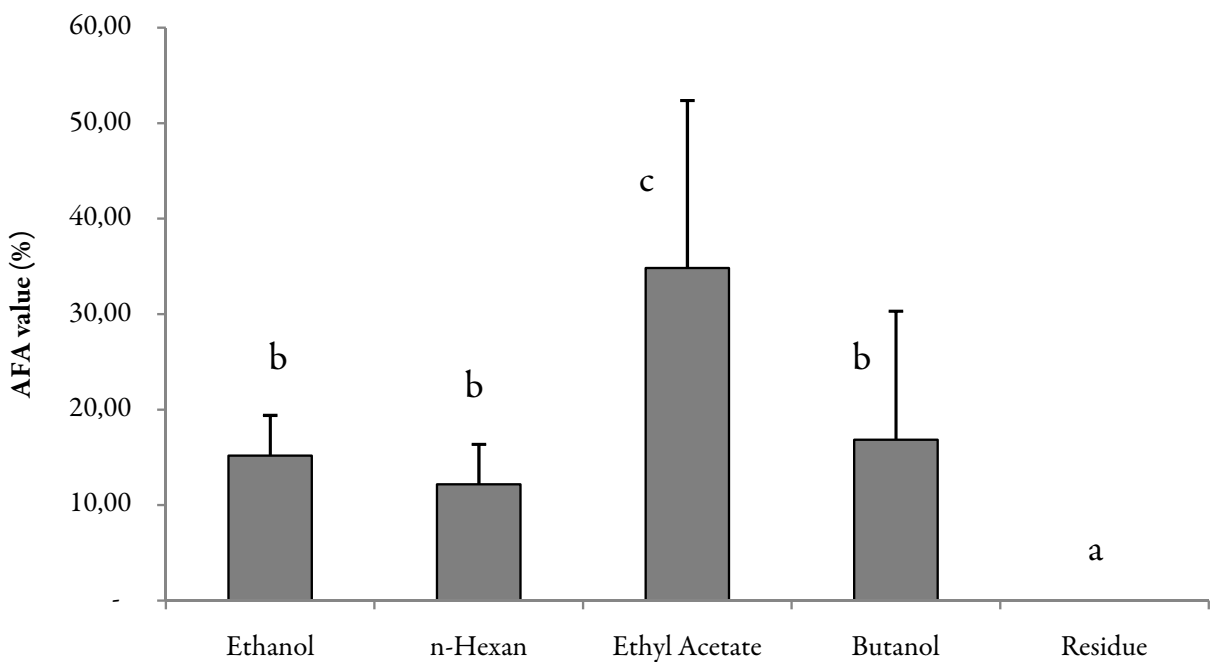

Figure 3. Average of AFA value of $A$. crassna's ethanol-soluble extracts and its corresponding fractions. The same letter at top of the bar indicated that the bars value were not significant different (Duncan Test, $\alpha$ 0.05) 
The residue fraction showed no anti fungal activities at all as the mycelia grew perfectly at media with residue fraction (Figures 2 and 3). The mycelia grew at residue fraction was at the same rate with that at the control media (Figure 4). Presumably, the residue might contain substances that in fact supported the life of the fungi; it might contain substances that are digestible and preferable by the fungi. Residue fraction in this study was assumed to contain the most-polar components of $A$. crassna wood extractives, that would be potential to be further dissolved in water. A study by Gite et al. (2010) indicated that water-soluble extract could contain sugar. However, the possible substance in residue fraction of this study should be further investigated. Kartal (2004) stated that residue fraction in his study could contain substances, such as vanillin and something else that are digestible and preferable by termite in the bioassay against termite.

Duncan's test showed that ethyl acetate-soluble fraction exhibited the highest AFA (Figures 2 and 3). Ethyl acetate as prepared at concentration 1\% and 2\% still showed low anti fungal activity (AFA $17.0 \%$ and $22.9 \%$, respectively), further it afforded AFA at moderate category at 3\% (27.0\%), and strong category at 4\% with AFA $52.5 \%$ (Figures 3 and 4).

In vitro assay of ethanol-soluble extract and its corresponding fractions to $F$. solani showed that the most bioactive compound against $F$. solani was in ethyl acetate fraction (Figure 3). This fact leads to an assumption that the agar tree contains this active compound at high level will probably be more resistant to Fsolani, which may suppress agarwood production. However, the situation might be different at field scale since there are many factors contribute to agarwood formation. Wood with higher extractives content is predicted to be more resistance against wood-decaying organism. However, the defense of the tree mostly depends on the type and concentration of bioactive compound within the extractives (Lestari and Pari, 1990). 


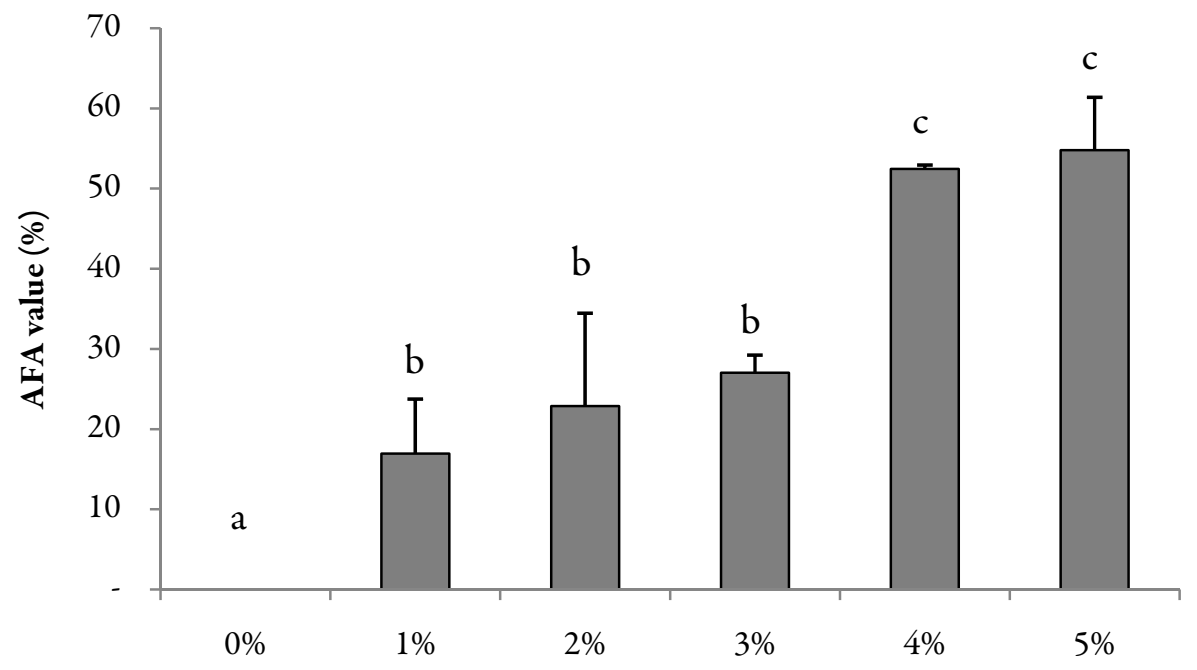

Concentration of ethyl acetate fractions

Figure 4. Averages of AFA (\%) at each concentration of ethyl acetate-soluble fraction. The same letter at top of the bar indicated that the bars value were not significant different (Duncan Test, $\alpha$ 0.05)

Many anti fungal and anti microbial compounds were produced from plant extractives. Mechanism of extractives in inhibiting fungal growth is assumed as the result of chemicals in interfering/stalling fungal enzyme activity to decompose carbohydrate into the simplest absorbable matter for fungi digestion and metabolism (Syafii et al. 1987; Jayasuriya et al., 2003; Mihara et al., 2005). As for A.crassna case here, some bioactive compounds within ethyl acetate-soluble fraction should affect $F$. solani fungi by inhibiting their mycelial growth. However, the concentration of the substance (fraction) should be high enough to inflict the inhibitory effect against $F$. solani growth, since it exhibited low level of AFA at 3\% of concentration but high AFA at $4 \%$ and so (Tables 1 and Figure 2). We suggest that $A$. crassna with high concentration of this ethyl acetate soluble fraction would be more resistant to agarwood forming by using F.solani. Supposedly, phenolics compounds and total flavanoids concentration level was higher in ethyl acetate fraction than in other fractions. Some studies mentioned that phenolics and flavanoids have antibacterial activity (Anushia et al., 2009) and could inhibit germination of fungi (Phongpaichit et al., 2004). 


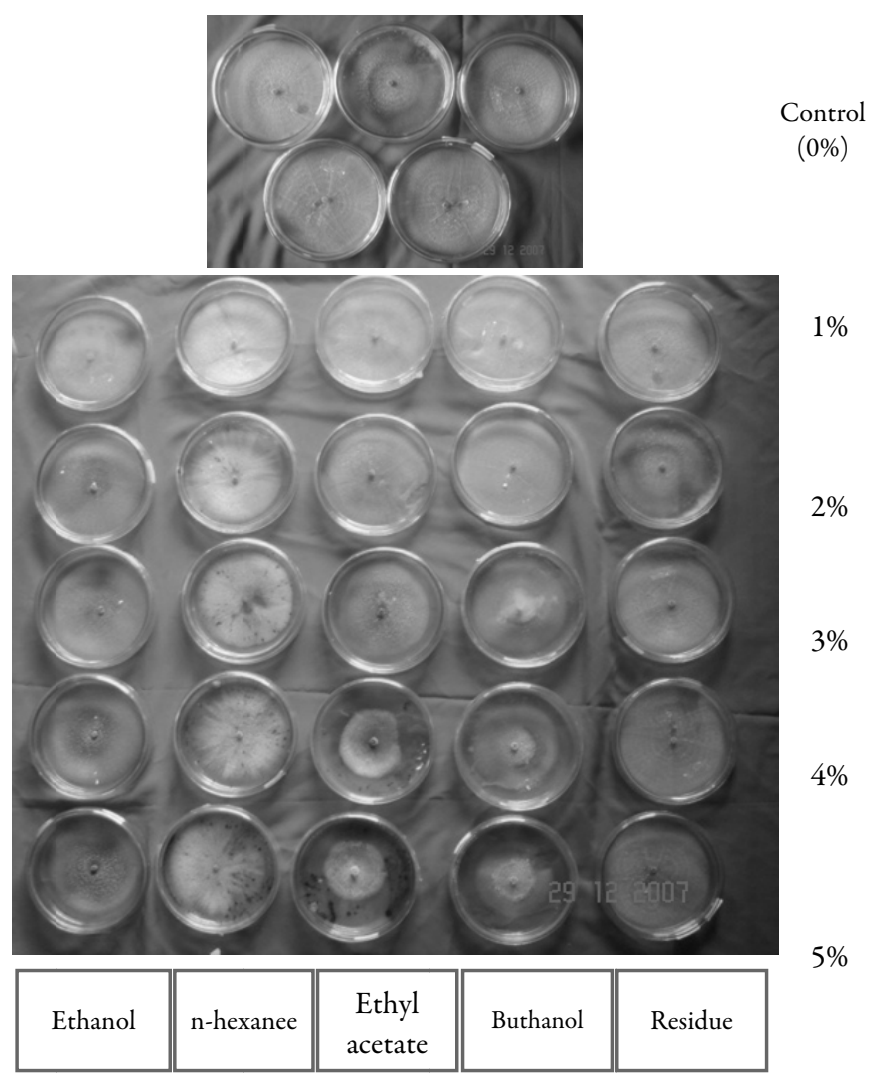

Figure 5. Mycelial growth of $F$. solani on agar plate with ethanol-soluble extract and its corresponding fraction

Agarwood producing trees will react to fungal infection in order to defend themselves and alleviate its condition. The resistance of the tree will settle on the winner; it would be the host or it would be the pathogen. In agarwood case, the pathogen is expected to win, so its formation could take place. Chemical compounds of the tree are those among defense systems against pathogen. The components in agarwood itself are already identified as sesquiterpenoid, a phytoalexin type in many plants defense compounds. How big the tree chemicals affect $F$. solani is considered to be related to the tree resistance against this fungus.

\section{CONCLUSIONS}

Aquilaria crassna had low extractive content that is $2.0 \%$ (w/w). Ethanol-soluble extract of $A$. crassna wood exhibit low class of antifungal activity against $F$. solani in vitro. 
Further fractionation of $A$. crasna ethanol-soluble extract revealed increasing antifungal activity. Ethyl acetate-soluble fraction showed the highest antifungal activity at $4 \%$ concentration that is categorized as strong class with AFA at $52.5 \%$.

It is important to examine further the most active single compound in ethyl acetatesoluble fraction of $A$. crassna wood, thus the agarwood with highest concentration of this compound could be excluded in artificial agarwood production.

\section{ACKNOWLEDGEMENT}

We thank the Ministry of Forestry, Government of Indonesia, Laboratory of Forest Microbiology of the Forest and Nature Conservation Research and Development Center (FNCRDC), and ITTO Project PD 425/06 Rev.1 (I) for funding the research. Specially, we thank Dr. G. Pari and Prof. S. Achmadi for their help and some discussions. We also thank all staff of Laboratory of Forest Microbiology of the FNCRDC, especially Mr. Najmulah and Mr. Yanto for their assistance in the work.

\section{REFERENCES}

Adelina, N. 2004. Seed Leaflet: Aquilaria malaccensis Lamc. Forest and Landscape Denmark. www.SL.kvl.dk. [2 Februari 2007].

Agrios, G.N. 1997. Plant Pathology. Fourth Edition. California: Academic Press.

Anushia, C., P. Sampathkumar and L. Ramkumar. 2009. Antibacterial and antioxidant activities in Cassia auriculata. Global Journal of Pharmacology 3(3): 127-130.

Barden, A., N.A. Anak, T. Mulliken and M. Song. 2000. Heart of the matter: agarwood use and trade and CITES implementation for Aquilaria malaccensis. www.traffic. org. [22 Mei 2007].

Blanchette, R.A. 2006. Sustainable agarwood production in Aquilaria trees. www. therainforestproject.net. [2 Februari 2007].

CITES. 2004. Convention on International Trade in endangered Species of Wild Fauna and flora: Amendments to Appendices I and II of CITES. http://www.cites.org/ common/cop/13/raw/props/ID-Aguilaria-gyrinops.pdf.

Gite, V.N., R.D. Pokharkar, V.V. Chopade and S.B. Takate. 2010. Evaluation of physicochemical standardization parameter of Enicostemma axillare. Journal of Bioscience Technology 1(4): 187-190.

Ishihara, M., T. Tsuneya, M. Shiga and K. Uneyama. 1991. Three Sesquiterpenes from Agarwood. Phytochemistry 30(2): 563-566.

Jayasuriya, K.E., R.L.C. Wijesundera and S.A. Deraniyagala. 2003. Isolation of antifungal phenolic compounds from petioles of two Hevea brasiliensis (rubber) 
genotypes and their effect on Phytophthora meadii. Annals of Applied Biology 142: 63-69.

Kartal. 2004. Preliminary evaluation of fungicidal and termicidal activities of filtrates from biomass slurry fuel production. Bioresource Technology 95: 41-47.

Lestari, S.B. and G. Pari. 1990. Analisis kimia beberapa jenis kayu Indonesia. Jurnal Penelitian Hasil Hutan 7(3): 96-100.

Mori, M., M. Aoyama, S. Doi, A. Kanetoshi and T. Hayashi. 1997. Antifungal activity of bark extract of deciduous trees. Holz als Roh und Werkstoff 55: 130-132.

Mihara, R., KM. Barry, C.L. Mohammed and T. Mitsunaga. 2005. Comparison of antifungal and antioksidant activities of Acacia mangium and Acacia auriculiformis heartwood extracts. Journal of Chemical Ecology 31(4): 789-804.

Novriyanti, E. 2008. Peranan zat ekstraktif dalam pembentukan gaharu pada Aquilaria crassna Pierre ex Lecomte dan Aquilaria microcarapa Baill. The Graduate School of Bogor Agricultural University. Bogor, Indonesia. (Unpublished thesis).

Persoon, G.A. and H.H. Van Beek. 2008. Growing 'the wood of Gods': agarwood production in Southeast Asia (abstract). Advance in Agroforestry 5(3): 245-262.

Pojanagaroon S. and C. Kaewrak. 2006. Mechanical methods to stimulate aloes wood formation in Aquiliria crassna Pierre ex H Lec (kritsana) trees. ISHS Acta Hort 676. www.actahort.org. [22 Mei 2007].

Phongpaichit, S., N. Pujenjob, V. Rukachaisirikul and M. Ongsakul. 2004. Antifungal activity from leaf extracts of Cassia alata, L., Cassia fistula L. and Cassia tora L. Journal of Science and Technology 26(5): 741-748.

Prema B.R. and P.K. Bhattacharrya. 1962. Microbial transformation of terpenes. National Chemical Laboratory. India.

Sumadiwangsa, E.S. and Harbagung. 2000. Growth rate of agarwood (Aquilaria malaccensis) stand in Riau that planted in high cultivation intensity and manual. Forest Product Info 6(1): 1-16.

Sumarna, Y. 2005. Teknologi Pengembangan Rekayasa Produksi Gaharu. Makalah pada Promosi Gaharu dan Mikoriza. Pekanbaru. (Unpublished paper).

Syafii, W., M. Samijima and T. Yoshimoto. 1987. The role of extractives in decay resistance of ulin wood (Eusideroxylon zwageri T. et B.). Bulletin of Tokyo University Forest 77: 1-8.

Wu, J-H., Y-T. Tung, S-Y. Wang, L-F. Shyur, Y-H. Kuo and S-T. Chang. 2005. Phenolic antioxidant from the heartwood of Acacia confusa. Journal of Agricultural and Food Chemistry 53: 5917-5921.

Yanti, H. 2008. Anti termitic properties of wood bark extractives of Acacia auriculiformis A.Cunn. ex Benth. The Graduate School of Bogor Agricultural University. Bogor, Indonesia. (Unpublished $\mathrm{PhD}$ thesis). 